脊髄 腫 痬 の 1 剖検 例

九州労災病院整形外科

$\begin{array}{llll}\text { 吉 村 } & \text { 理・岩 淵 } \\ \text { 赤津 } & \text { 隆・北 野 元 生 }\end{array}$

\title{
Spinal Cord Tumor Manifested Initially by Insidious Onset of Scoliosis A Case Report
}

by

\author{
O. Yoshimura, A. Iwabuchi, T. Akatsu \\ and M. Kitano
}

Orthopedic Surgery Kyushu Rosai Hospital, Fukuoka

\begin{abstract}
An autopsy case of 19-year-old female is reported. She was affected with spinal cord tumor with major involvement of the upper thoracic segments. Initial onset was solely manifested by scoliosis and the scoliosis had been treated with Milwaukee brace for five years. Within next two years she gradually lapsed into apparent paraplegia and then died of pneumonia. Massive growth of anaplastic ganglioglioma in the upper thoracic segments $\left(\mathrm{T}_{1}-\mathrm{T}\right)$ was disclosed by pathological-anatomical examination.
\end{abstract}

\section{1. はじめに}

脊喣腫瘍は稀な疾患ではないが，その臨床症状は多 彩であり，診断は必ずしも容易ではない，今回われわ れは側彎を主訴として来院し特発性側彎症と䜽断し治 療していた奉㭪过々内腫瘍の一培検例を経験したので, 報告する.

\section{2. 症例}

\section{9 歳 女性}

昭和 46 年 5 月（当時 13 才）学校検晾にて側彎を指 摘され当院初診した. レントゲン㭘査にて図 1 に示す 如くCobb 法 28 度の左凸胸椎カーブであり, 特発性 側彎症と診断しミルウォーキー装具装敾とともに運動 療法にて外来経過観察していた. なお初診時神経学的 には特記すべきことはなかった．昭和 47 年 5 月 側彎 增強せず，この時両滕蓋腱反射・アキレス腱反射六進 し，バビンスキー反射陽性であることに気付き精查し たが，マルファン症候群など間葉系疾患は否定され， 神経内科の診断では特発性㾏性脊梿性対麻疩とのとと であった．昭和 51 年 1 月（当時 18 才）側彎増強せず ミルウォーキー装具除去，乙の間両下肢の氫性は中等
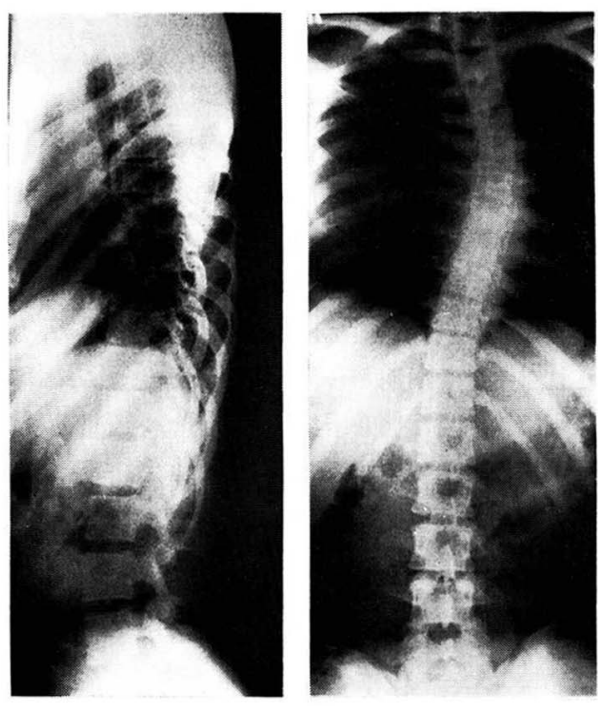

図 1

度であったが日常生活に制限はなかった．昭和 51 年 10 月, 連動会の徒競争で足があつれて転倒してより雨 下肢の脱力を生じ，起立歩行不能となり精査目的にて 入院した. 入院時自発痛・压痛など疼痛はなく，両下 肢の痙性は強く迗動麻痛は認められたが，知覚障害は 
なく，膀胱直腸障害む認められなかった．腰檤穿刺を 行ない，初压 $100 \mathrm{mmH}_{2} \mathrm{O}$, クエッケンステッド陽 性, 蛋白 $250 \mathrm{mg} / \mathrm{dl}$, 細胞数 8 , ノンネアペルト反 応，パンディ反応陽性で，脊䯣閉塞所見を示し，穿刺 後第 6 胸䯣以下知覚鈍麻, 膀胱直腸障害が出現した. 11 月 12 日脊骾造影を行なったが, 第 2 胸椎以下完全 ストップ像を示した．春䯣腫湟の診断のもとに手術を 施行したが，第 1 胸椎より第 4 胸椎の椎弓切除を行な うに硬膜外脂肪組織は消失し, 脊䯣が著じるしく增大 しており, 硬膜に正中切開を加えるに, 暗赤色出血性 浸潤性の腫瘍組織が膨隆し，境界不明瞭であった．可 及的に摘出したが, 病理検查では中等度の異型性を示 すガングリオグリオーマであった，術後コバルト照射 を 1 クール行ない，第 5 胸䯣以下完全麻㾇の状態でリ ハビリテーションを施行した. しかし両下肢の痤性が 強く, リハビリテーション上制限があり，また膀腅内 圧曲線で自働膀胱を示し, 残尿が多く尿失禁もみられ たので，昭和 52 年 5 月第 $3 \sim 4$ 腰椎間に $5 \%$ $\%$ ノ ールグリセリンを用いて脊䯣ブロックを行なった，以 後自己導尿可能となり車椅子駆動，骨盤带付長下肢装 具にての歩行など，日常生活動作は自立した. しかし 麻㾝域は徐々に上昇して行き, 昭和 52 年 12 月呼吸筋 麻痐に肺炎を合併し，炤和 53 年 2 月死亡した。

\section{3. 剖 検 所見}

第 4 胸椎より第 8 胸椎まで腫煬が椎管外へ㳔潤して おり, 脊㭪道後面の縦走静脈の怒張が著るしく, 循環障 害を示している. 図 2 に示す如く第 5 胸髅の横断面で は脊髄が完全に腫瘍におきかわっており，また胸髄の 腫瘍の浸潤以外飞, 頸䯣腰䯣に循環障害に上ると思わ れる空洞之壊死巣の発生がみられる. 組織学的には, 生検時之同様のガングリオグリオーマの像の他に, 腫 陽の大部分は多形膠芽細胞腫の像を呈し（図 3，4，

$5)$ ，生検時の所見之はかなりその様相が異なってい る.フェノールブロックを行なったが，馬尾神経では 軽度の脱䯣がみられた，直接死因は気管支肺炎である と考えられた。

\section{4. 考案}

側彎と脊䯣腫瘍との関係は，(1) 特発性側彎症と金 剈道腫瘍の合併. (2) 腫瘍による機能性側彎. の二つが 考えられる. 全経過を通じて疼痛はなく, 疼痛による 偏側性の持続性筋緊張による側彎とは考えられず，レ

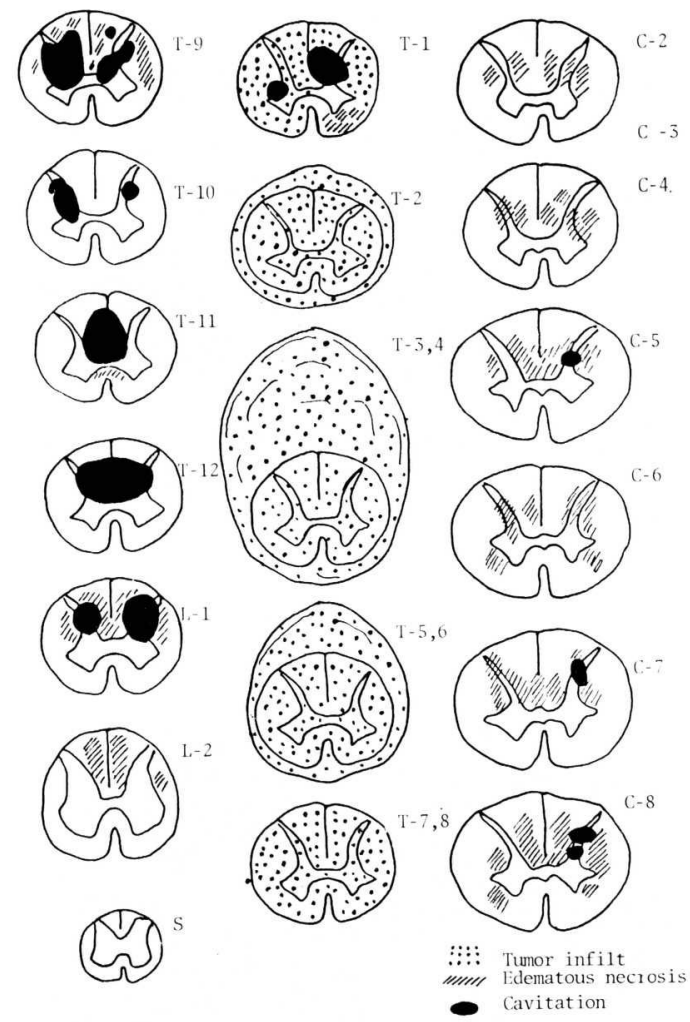

図 2

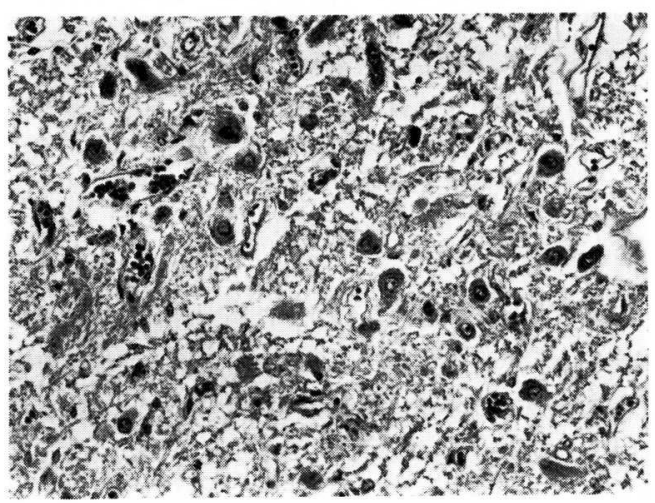

図3腫湯の組織像。ニッスル顆粒を有する神経 節紐胞様細胞の增殖を示亦部位. 腫瘍細胞 の異型性はそしく，核分裂像もみられない。 上部胸髄, $\mathrm{H}-\mathrm{E}, \times 250$

ントゲン所見からみても，左凸胸椎カーブではある が，脊䯣腫癔之特発性側彎症の合併之考元たい。 


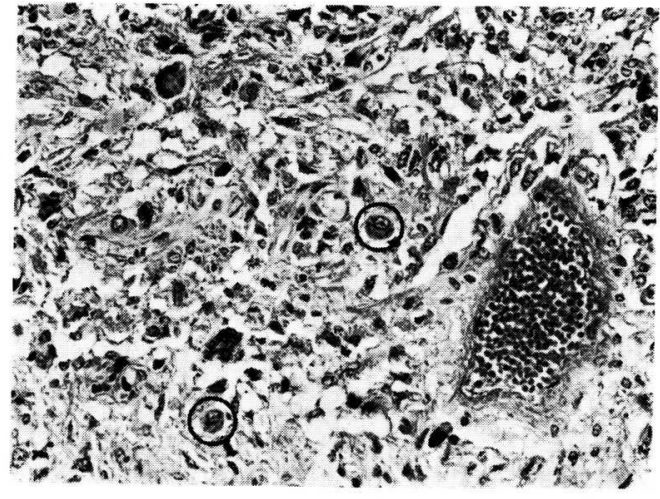

図4腫瘍の組織像. 多型膠芽細胞を思わせる部 位. 神経膠紐胞系細胞と巨細胞形成がみら れる. 2 ケの神経節細胞様組胞の混在が認 められる。(円内). 上部胸髄, H-E, 250

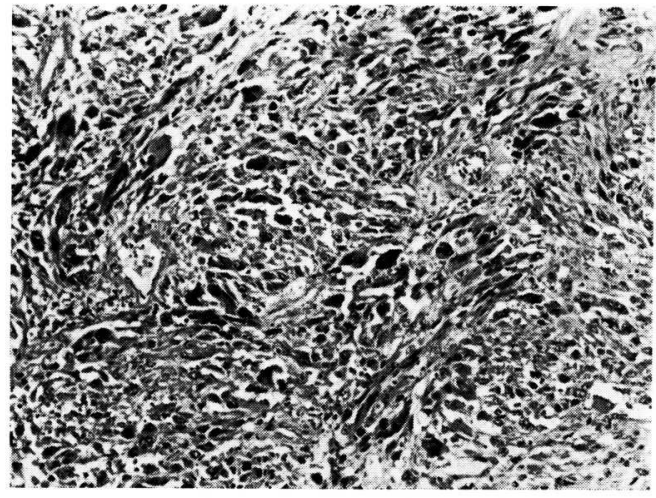

図 5 腫瘍の組織像. 多型膠芽細胞を思わせる像。 多型性を示す神経膠細胞系細胞の增殖が著 明である。上部胸骨道, H-E, × 125

5. 結 び

経過中両下肢の痙性に気付いたが，思春期の特発性 側彎症として治療していた症例であるが，特発性側彎 症と脊骾腫瘍の合併と考えた．病理学的には多形膠芽
細胞腫であった。

（稿を終えるに当り，終始激励を賜った天児民和九 州労災病院長に深謝致します.)

\section{文献}

1）岩原寅猪：脊髄腫瘍. 日本外科全書. 12:175, 南江堂, 東京, 1956.

2) 真鍋昌平ほ力: 脊随腫璄の検討. 中部整災誌. $20(4): 641-662$, 昭52。

3）鈴木邦雄ほか：䯣液採取など検查によって症状 悪化を来たした春髄腫瘍例．中部整災誌，20(6)： 857-861, 昭52.

4) 宮本ほか：脊髄腫湟の5 例. 整形外科と災害外 科. $21: 204-207,1972$.

5) 山田憲吾編：脊柱変形. 医学書院, 東京, 1977 .

6）川上俊文ほか：我が教室における脊髄腫場につ いて。中部整災誌。20(2): 285-289, 昭52.

7) Da Rosa. A. C.: Primary intra Spinal Tumors. J. Bone Joint Surg., 46B: 8-19, 1964.

8) Greenwood, J.: Intramedullary Tumors of Spinal Cord. J. Neurosurg., 20: 665-676, 1963.

9) Mason, T. M. : Intramedullary Spinal Neurilemmoma, J. Neurosurg., 29: 414-420, 1968.

10) Wood, W. G.: Intramedullary Neurilemmoma of the Cervical Spinal Cord, J. Neurosurg., 42: 465-474, 1975 .

質 問山口大学整形 服 部 奖 死亡原因について, 腫瘍の上方への進展による呼吸 麻漸によるものですか.

解 答 九州労災病院 吉 村 理

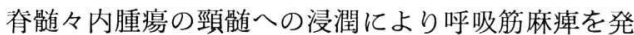
生し死亡した症例である。 